Revista de Metalurgia 50(1)

January-March 2014, e002

ISSN-L: 0034-8570

doi: http://dx.doi.org/10.3989/revmetalm.002

\title{
Galvanic corrosion of rare earth modified AM50 and AZ91D magnesium alloys coupled to steel and aluminium alloys
}

\author{
Marta Mohedano ${ }^{\mathrm{a}}$, Raúl Arrabal ${ }^{\mathrm{a}, \varpi}$, Angel Pardo $^{\mathrm{a}}$, Karín Paucar $^{\mathrm{b}}$, M. Concepción Merino ${ }^{\mathrm{a}}$, \\ Endzhe Matykina ${ }^{\mathrm{a}}$, Beatriz Mingo ${ }^{\mathrm{a}}$, Gerardo Garcés ${ }^{\mathrm{c}}$ \\ ${ }^{a}$ Departamento de Ciencia de Materiales, Facultad de Químicas, Universidad Complutense, 28040 Madrid, España

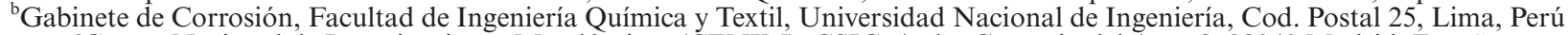 \\ ${ }^{\circ}$ Centro Nacional de Investigaciones Metalúrgicas (CENIM). CSIC, Avda. Gregorio del Amo 8, 28040 Madrid, España \\ Corresponding autor: raularrabal@quim.ucm.es
}

Submitted: 19 March 2013; Accepted: 16 July 2013

SUMMARY: Electrochemical and gravimetric measurements were used to examine the effects of neodymium and gadolinium additions on the galvanic corrosion behaviour of AM50 and AZ91D magnesium alloys coupled to A 570 Gr 36 carbon steel and AA2011-AA6082 aluminium alloys. Rare earth modified alloys showed $\mathrm{Al}_{2} \mathrm{Nd} / \mathrm{Al}_{2} \mathrm{Gd}$ and $\mathrm{Al}-\mathrm{Mn}-\mathrm{Nd} / \mathrm{Al}-\mathrm{Mn}-\mathrm{Gd}$ intermetallics, reduced area fraction of $\beta-\mathrm{Mg}_{17} \mathrm{Al}_{12}$ phase and increased corrosion resistance due to increased surface passivity and suppression of micro-galvanic couples. Neodymium and gadolinium additions improved the galvanic corrosion resistance of AM50 alloy, but were less effective in case of the AZ91D alloy. The AA6082 alloy was the most compatible material and the AA2011 alloy was the least compatible.

KEYWORDS: Galvanic corrosion; Magnesium alloys; Polarization; Weight loss

Citation / Cómo citar este artículo: Mohedano, M., Arrabal, R., Pardo, A., Paucar, K., Merino, M.C., Matykina, E., Mingo, B., Garcés, G. (2014) "Galvanic corrosion of rare earth modified AM50 and AZ91D magnesium alloys coupled to steel and aluminium alloys". Rev. Metal. 50(1): e002. doi: http://dx.doi.org/10.3989/revmetalm.002

RESUMEN: Corrosión galvánica de aleaciones de magnesio AM50 y AZ91D modificadas con tierras raras en contacto con acero y aleaciones de aluminio. Se emplearon medidas electroquímicas y gravimétricas para examinar el efecto de la adición de neodimio y gadolinio en el comportamiento a la corrosión galvánica de las aleaciones AM50 y AZ91D en contacto con acero al carbono A 570 Gr 36 y aleaciones de aluminio AA2011 y AA6082. Las aleaciones modificadas con tierras raras mostraron intermetálicos $\mathrm{Al}_{2} \mathrm{Nd} / \mathrm{Al}^{2} \mathrm{Gd}$ y $\mathrm{Al}-\mathrm{Mn}-\mathrm{Nd} / \mathrm{Al}-\mathrm{Mn}-\mathrm{Gd}$, menor fracción de fase $\beta-\mathrm{Mg}_{17} \mathrm{Al}_{12} \mathrm{y}$ un incremento de la resistencia a la corrosión debido al aumento de la pasividad de la superficie y a la eliminación de micro pares galvánicos. Las adiciones de neodimio y gadolinio mejoraron la resistencia a la corrosión galvánica de la aleación AM50, pero fueron menos efectivas en el caso de la aleación AZ91D. La aleación AA6082 fue el material más compatible y la aleación AA2011 el menos compatible.

PALABRAS CLAVE: Aleaciones de magnesio; Corrosión galvánica; Pérdida de masa; Polarización

Copyright: (C) CSIC. This is an open-access article distributed under the terms of the Creative Commons AttributionNon Commercial (by-nc) Spain 3.0 License. 


\section{INTRODUCTION}

The search for lightweight solutions in the automobile industry, driven by the necessity to reduce energy consumption and air pollution, has renewed the interest for magnesium alloys which, due to their combination of low density (35\% lighter than aluminium and over four times lighter than steel) and excellent physical and mechanical properties, are ideal candidates for replacing heavier materials in components such as engine valve covers, front ends, instrument panels, radiator supports, door and liftgate inners, seat structures, etc. (Friedrich and Schuman, 2001; Luo, 2004).

Galvanic corrosion of magnesium is of major concern in industrial design and material selection. This is because magnesium is the most active structural metal in the electromotive force series, and therefore is susceptible to galvanic corrosion when in contact with commonly used materials such as aluminium alloys and steel (ASTM, 1998; Song and Atrens, 1999; Makar and Kruger, 1990; Zeng et al., 2006). The materials most compatible with magnesium are those that provide the lowest potential difference and the largest polarization resistance. Zinc and aluminium alloys of the $5 \mathrm{xxx}$ and $6 \mathrm{xxx}$ series are among the most compatible materials, whereas materials such as steels, copper and nickel alloys are not compatible due to their significant potential difference (Skar and Albricht, 2002).

In order to understand and improve the galvanic corrosion behaviour of magnesium alloys, several areas have been investigated. These normally include galvanic compatibility studies and the effects of geometric factors - anode to cathode area ratio, insulation distance between anode and cathode, electrolyte film depth, shapes of the anode and cathode (Jia et al., 2006; Liu, et al., 2009a; Song, 2010). However, there is little information available on the effect of small compositional changes on the galvanic corrosion behaviour of magnesium alloys. In this sense, the effect of small additions of Rare Earth (RE) elements is of particular interest, as they have already proved to be effective in diminishing the corrosion rate of Mg-Al alloys (Yamasaki, 2007; Yue and Sha, 2007) due to a combination of several factors: (i) improved passivation properties (Nordlien et al., 1997); (ii) suppression of microgalvanic couples due to substitution of Al-Mn inclusions by Al-RE phases with lower potential values (Song et al., 2007; Zhang et al., 2008; Liu et al., 2009b; Zhang et al., 2011); (iii) incorporation of $\mathrm{RE}$ in the $\mathrm{Mg}(\mathrm{OH})_{2}$ lattice (Rosalbino et al., 2005); (iv) entrapment of impurities in RE-containing intermetallic compounds (Mercer and Hillis, 1992) and $(\mathrm{v})$ formation of a more uniform $\beta$-phase network (Niu et al., 2008; Zhao et al., 2008; Zhang et al., 2009; Guo et al., 2010; Nayyeri et al., 2011). Previous results of the authors carried out in aqueous solution revealed that the addition of $0.7-0.8$ wt. $\%$ Nd reduced the corrosion rate of AM50 and AZ91D alloys by $\sim 90 \%$, whereas further addition of neodymium (1.4-1.5 wt.\%) only reduced the corrosion rate between $\sim 60 \%$ and $90 \%$ (Arrabal et al., 2012a). However, investigations are still needed to confirm whether this improvement in the self-corrosion behaviour of $\mathrm{Mg}-\mathrm{Al}$ alloys is also observed in a galvanic couple.

With respect to the techniques available for estimating the galvanic corrosion rate, the majority of studies are focused on numerical methods to predict the galvanic current density distribution (Mc Cafferty, 1976; Melville, 1980; Aoki and Kishimoto, 1991; Desphande, 2010a; Desphande, 2011). However, those models are developed for conventional metals and may not work on magnesium alloys due to their special electrochemical behaviour, called "negative difference effect" (Makar and Kruger, 1993; Song and Atrens, 2000). From the design point of view, just an overall galvanic corrosion evaluation of the magnesium alloys in contact with other materials such as alumunium or steel (including fastener) is sufficient in order to evaluate their compatibility. These types of studies are based on the measured weight loss, the penetration depth, the total galvanic current and the visual observation of the corrosion damage on the whole magnesium component (Skar, 1999; Senf et al., 2000; Song et al., 2004; Desphande, 2010b).

The aim of this study was to evaluate the galvanic corrosion behaviour of AM50 and AZ91D magnesium alloys modified with RE additions in contact with two aluminium alloys and mild steel, using both electrochemical and gravimetric measurements.

\section{MATERIALS AND METHODS}

\subsection{Test materials}

Three types of materials were used in these experiments: Mg-Al alloys, steel and aluminium alloys. AM50 and AZ91D Mg-Al alloys are commonly used in the automobile industry, A $570 \mathrm{Gr} 36$ steel is a general purpose steel and AA2011/AA6082 aluminium alloys are good representatives of aluminium alloys of the 2xxx and 6xxx series. The chemical composition of A $570 \mathrm{Gr} 36$ steel is $0.25 \mathrm{C}, 0.90 \mathrm{Mn}, \leq 0.045 \mathrm{P}$, $\leq 0.05 \mathrm{~S}, 0.2 \mathrm{Cu}$, balance $\mathrm{Fe}$ (wt.\%). The composition of the AA2011 alloy is $0.13 \mathrm{Si}, 0.34 \mathrm{Fe}, 5.25 \mathrm{Cu}$, $0.05 \mathrm{Zn}, 0.42 \mathrm{Bi}, 0.38 \mathrm{~Pb}, 0.03 \mathrm{Mn}$, balance $\mathrm{Al}(\mathrm{wt} . \%)$ and the composition of the AA6082 alloy is $0.87 \mathrm{Si}$, $0.25 \mathrm{Fe}, 0.02 \mathrm{Cu}, 0.62 \mathrm{Mn}, 0.84 \mathrm{Mg}, 0.02 \mathrm{Zn}, 0.02 \mathrm{Ti}$, $0.02 \mathrm{Cr}$, balance $\mathrm{Al}$ (wt.\%). The nominal compositions of magnesium alloys, determined by wavelength 
TABLE 1. Chemical composition of the studied alloys

\begin{tabular}{lccccccccc}
\hline & \multicolumn{10}{c}{ Elements (wt.\%) } \\
\cline { 2 - 11 } Material & Al & Mn & Zn & Gd & Nd & Cu & Fe & Si & Mg \\
\hline AM50 & 4.9 & 0.26 & $<0.2$ & - & - & $<0.006$ & $<0.004$ & $<0.06$ & Bal. \\
AM50GdB & 4.0 & 0.30 & $<0.2$ & 0.7 & - & $<0.006$ & $<0.004$ & $<0.06$ & Bal. \\
AM50GdA & 4.4 & 0.24 & $<0.2$ & 1.0 & - & $<0.006$ & $<0.004$ & $<0.06$ & Bal. \\
AM50NdB & 4.4 & 0.21 & $<0.2$ & - & 0.8 & $<0.006$ & $<0.004$ & $<0.06$ & Bal. \\
AM50NdA & 4.0 & 0.24 & $<0.2$ & - & 1.5 & $<0.006$ & $<0.004$ & $<0.06$ & Bal. \\
AZ91D & 8.9 & 0.19 & 0.52 & - & - & $<0.001$ & $<0.004$ & $<0.01$ & Bal. \\
AZ91DGdB & 8.9 & 0.15 & 0.52 & 0.2 & - & $<0.001$ & $<0.004$ & $<0.01$ & Bal. \\
AZ91DGdA & 8.0 & 0.14 & 0.52 & 0.7 & - & $<0.001$ & $<0.004$ & $<0.01$ & Bal. \\
AZ91DNdB & 8.1 & 0.13 & 0.52 & - & 0.7 & $<0.001$ & $<0.004$ & $<0.01$ & Bal. \\
AZ91DNdA & 8.1 & 0.16 & 0.52 & - & 1.4 & $<0.001$ & $<0.004$ & $<0.01$ & Bal. \\
\hline
\end{tabular}

dispersion X-ray fluorescence (Pananlytical Axios), are given in Table 1. AM50 and AZ91D alloy ingots (Magnesium Elektron Ltd., U.K.) and neodymium and gadolinium $(99.9 \%$, Metall Rare Earth Ltd., China) were used to prepare the alloys.

Melting was carried out in an electrical furnace held at $740^{\circ} \mathrm{C}$ under Foseco MAGREX 60 covering flux to protect molten magnesium from oxidation. Neodymium or gadolinium was added to the melt and held for 30 minutes to ensure complete dissolution. The obtained gravity cast billets of $45 \mathrm{~mm}$ diameter were homogenized at $350^{\circ} \mathrm{C}$ for 24 hours, air cooled and then rectified to $40 \mathrm{~mm}$ diameter before extrusion at $350{ }^{\circ} \mathrm{C}$ with an extrusion ratio of $4: 1$ and an extrusion rate of $0.4 \mathrm{~mm} \mathrm{~s}^{-1}$. A stressrelief treatment at $350^{\circ} \mathrm{C}$ for 2 hours was performed on the extruded bars, which were finally sectioned into $2.5 \mathrm{~mm}$ thick specimens.

\subsection{Specimen preparation and characterization}

For metallographic characterization, samples were wet ground through successive grades of silicon carbide abrasive papers from P120 to P1200, followed by diamond finishing to $0.1 \mu \mathrm{m}$. Acetic-picral reagent $(4.2 \mathrm{~g}$ picric acid $+10 \mathrm{~mL}$ acetic acid $+70 \mathrm{~mL}$ ethanol $+10 \mathrm{~mL} \mathrm{H}_{2} \mathrm{O}$ ) was used to reveal the grain boundaries and constituents of the magnesium alloys. Prior to electrochemical and gravimetric measurements, the specimens were wet ground to P2000 finish, degreased in isopropyl alcohol in an ultrasonic bath and dried in warm air.

Samples were examined with a Scanning Electron Microscope (SEM, Jeol JSM-6400) equipped with Oxford Link energy-dispersive X-ray (EDX) microanalysis hardware. For X-Ray Diffraction (XRD) studies, a Philips X'Pert diffractometer $(\mathrm{Cu} \mathrm{K}=1.54056 \AA)$ was used.

Surface potential maps of polished magnesium alloys were obtained with a Nanoscope IIIa MultiMode Atomic Force Microscope (AFM, Veeco-Digital
Instruments) working in tapping mode in order to obtain information on the local nobility of the microconstituents of the studied alloys on a submicron scale. A silicon tip with a platinum-coating of $20 \mathrm{~nm}$ thickness was used for simultaneous acquisition of topographic and surface potential images. The AFM tip was calibrated by performing a potential ramp on a reference sample consisting of aluminium coated with a thin gold layer. The tip to sample distance was kept constant at $50 \mathrm{~nm}$ using a two-pass technique, where the height data is recorded in tapping mode during the first pass and the tip lifts above the surface to an adjustable lift height and scans the same line while following the height profile recorded in the first pass. All measurements were made at room temperature with a relative humidity in the range of $40-65 \%$.

\subsection{Electrochemical measurements}

\section{Potentiodynamic curves}

An AUTOLAB computer-controlled potentiostat (PGSTAT 30) connected to a three-electrode cell was used for the electrochemical measurements. The working electrode was the test material with an immersed area of $0.3 \mathrm{~cm}^{2}$ and graphite and silver/ silver chloride $(\mathrm{Ag} / \mathrm{AgCl})$ electrodes were used as the counter and reference electrodes, respectively. The solution concentration inside the reference electrode compartment was $3 \mathrm{M} \mathrm{KCl}$, providing a potential of $0.197 \mathrm{~V}$ with respect to the standard hydrogen electrode. The test solution was naturally-aerated $3.5 \mathrm{wt} \% \mathrm{NaCl}$ solution at room temperature $\left(22^{\circ} \mathrm{C}\right)$ and $\mathrm{pH} 6.5$, though the $\mathrm{pH}$ changed freely during the experiment. Electrochemical measurements were performed twice to ensure the reproducibility of the results.

Potentiodynamic polarisation curves were obtained after immersion for 1 hour at a scanning rate of $0.3 \mathrm{mV} \mathrm{s}^{-1}$, starting from $-1100 \mathrm{mV} v s$. the open circuit potential (OCP), for steel and aluminium 
alloys, and from $-150 \mathrm{mV}$ vs. OCP for magnesium alloys. In all measurements the polarisation stopped at a maximum current of $5 \mathrm{~mA} \mathrm{~cm}{ }^{-2}$. Based on the mixed potential theory, the corrosion potential, $E_{M}$, and the current density, $i_{M}$, of the galvanic couples were estimated from the polarization behaviour of the constituent individual alloys of equal area ratio by overlaying their polarization curves. The corrosion rate, $P_{M}\left(\mathrm{mg} \mathrm{cm} \mathrm{cm}^{-2}\right)$, was calculated from current density, $i_{c}\left(\mathrm{~mA} \mathrm{~cm}{ }^{-2}\right)$, using the following conversion equation (1), (Shi et al., 2010).

$$
P_{M}=10.85 i_{M}
$$

\section{Zero-resistance ammeter (ZRA) measurements}

The galvanic current measurements, known as ZRA measurements, were obtained with an AUTOLAB PGSTAT30 potentiostat working as a zero-resistance ammeter. Specimens of $\sim 1.4 \mathrm{~cm}^{2}$ were separated at a fixed distance of $2 \mathrm{~cm}$ and a copper plate was used as a direct electrical contact. The gap distance was selected as to guarantee uniform galvanic corrosion of the anode and galvanic protection of the cathode (over the anode and cathode surfaces) and as to avoid any significant influence from the geometry in the galvanic cell, i.e. shape, orientation and size of the electrodes.

The average galvanic current density, $i_{Z R A}^{A}$, was calculated from the galvanic current, $i_{Z R A}$, measured during the experimental period (1 day in this work) through the following equation (2), (Bellucci, 1991; Dong et al., 2010).

$$
i_{Z R A}^{A}=\frac{1}{T} \int_{0}^{T} i_{Z R A}(t) d t
$$

where $T$ is total experimental period. The galvanic corrosion rate, $P_{Z R A}\left(\mathrm{mg} \mathrm{cm}^{-2} \mathrm{~d}^{-1}\right)$, can be calculated from $i_{Z R A}^{A}$ using the same conversion factor as in equation (1).

\subsection{Weight loss measurements}

Gravimetric measurements were performed using specimens of $\sim 1.4 \mathrm{~cm}^{2}$ that were weighed before and after immersion in $3.5 \mathrm{wt} . \% \mathrm{NaCl}$ solution at $22{ }^{\circ} \mathrm{C}$ for 1 day using a Sartorius BP 211D scale with an accuracy of $0.01 \mathrm{mg}$. Metal loss of magnesium alloys was calculated by weighing the specimens after pickling in a solution of $200 \mathrm{~g} \mathrm{~L}^{-1} \mathrm{CrO}_{3}$ and $10 \mathrm{~g} \mathrm{~L}^{-1}$ $\mathrm{AgNO}_{3}$ at room temperature for 5-10 minutes. The cited corrosion rate values, $P_{W}\left(\mathrm{mg} \mathrm{cm}^{-2} \mathrm{~d}^{-1}\right)$, are the average of three specimens.

\subsection{Characterization of corrosion products}

The investigated magnesium alloys were characterized by Scanning Electron Microscopy (SEM) and low-angle X-ray Diffraction (XRD) after the galvanic corrosion tests in order to study the corrosion morphology and the influence of the lanthanide elements additions in the morphology and composition of the corrosion products.

\section{RESULTS AND DISCUSSION}

\subsection{Microstructural characterization}

The optical micrographs of the unmodified AM50 and AZ91D alloys, in the transverse section relative to the extrusion direction, revealed equiaxial $\alpha-\mathrm{Mg}$ grains with an average size of $\sim 6.6$ and $\sim 6.0 \mu \mathrm{m}$, respectively, and coarse $\mathrm{b}-\mathrm{Mg}_{17} \mathrm{Al}_{12}$ particles (Fig. 1a and Fig. 1b).

The presence of aluminium and manganese in both alloys resulted in the formation of Al-Mn phases with an average composition, according to EDX analysis, of 70.2Al-29.5Mn-0.3Fe (at.\%) and 65.6Al-34.2Mn-0.2Fe (at.\%) for the AM50 and AZ91D alloys, respectively. A higher area fraction of $\beta-\mathrm{Mg}_{17} \mathrm{Al}_{12}$ phase was observed in the AZ91D alloy ( $\mathrm{f} \beta=\sim 7.1 \%$ ), due to its higher aluminium content compared with the AM50 alloy ( $\mathrm{f} \beta=\sim 0.5 \%$ ).

Small neodymium or gadolinium additions (0.7 wt. \% Gd-0.8 wt.\% Nd) were mainly present in Al-Mn-Nd or Al-Mn-Gd inclusions, with an average composition of $63 \mathrm{Al}-27 \mathrm{Mn}-10 \mathrm{Nd}$ (at.\%) and 67Al-25Mn-8Gd (at.\%), respectively. Higher concentrations ( 1 wt. $\%$ Gd-1.5 wt. $\% \mathrm{Nd}$ ) favoured the formation of $\mathrm{Al}_{2} \mathrm{Nd}$ or $\mathrm{Al}_{2} \mathrm{Gd}$ intermetallics as indicated by XRD results (Fig. 2).

Similarly to the Al-Mn inclusions in the unmodified alloys, both $\mathrm{Al}_{2} \mathrm{Nd} / \mathrm{Al}_{2} \mathrm{Gd}$ and $\mathrm{Al}-\mathrm{Mn}-\mathrm{Nd} /$ Al-Mn-Gd intermetallic compounds scavenged some iron from the $\alpha-\mathrm{Mg}$ matrix. The area fraction of $\mathrm{Nd}$ - and Gd-containing intermetallics was between $\sim 0.3$ and $\sim 2.1 \%$ for the modified alloys, which was higher than that of Al-Mn inclusions in the unmodified alloys ( $\mathrm{f} \beta=\sim 0.2 \%$ ) (Fig. 1c and Fig. 1d). The higher number of aluminium atoms consumed by the formation of $\mathrm{Nd}$ - and Gd-containing intermetallics led to a visible reduction in the area fraction of b-phase until its almost complete elimination at high neodymium and gadolinium concentrations, i.e., down to $\sim 0.1 \%$ and $\sim 2.6 \%$ for the AM50NdA and AZ91DNdA alloys. The grain size of the $\alpha-\mathrm{Mg}$ phase remained relatively unchanged $(6.1-7.7 \mu \mathrm{m})$ for the AM50 alloy; however, in case of the modified AZ91D alloy, significant grain coarsening was observed $(\sim 11 \mu \mathrm{m})$, possibly associated with the large reduction in the amount of $\beta$-phase. 

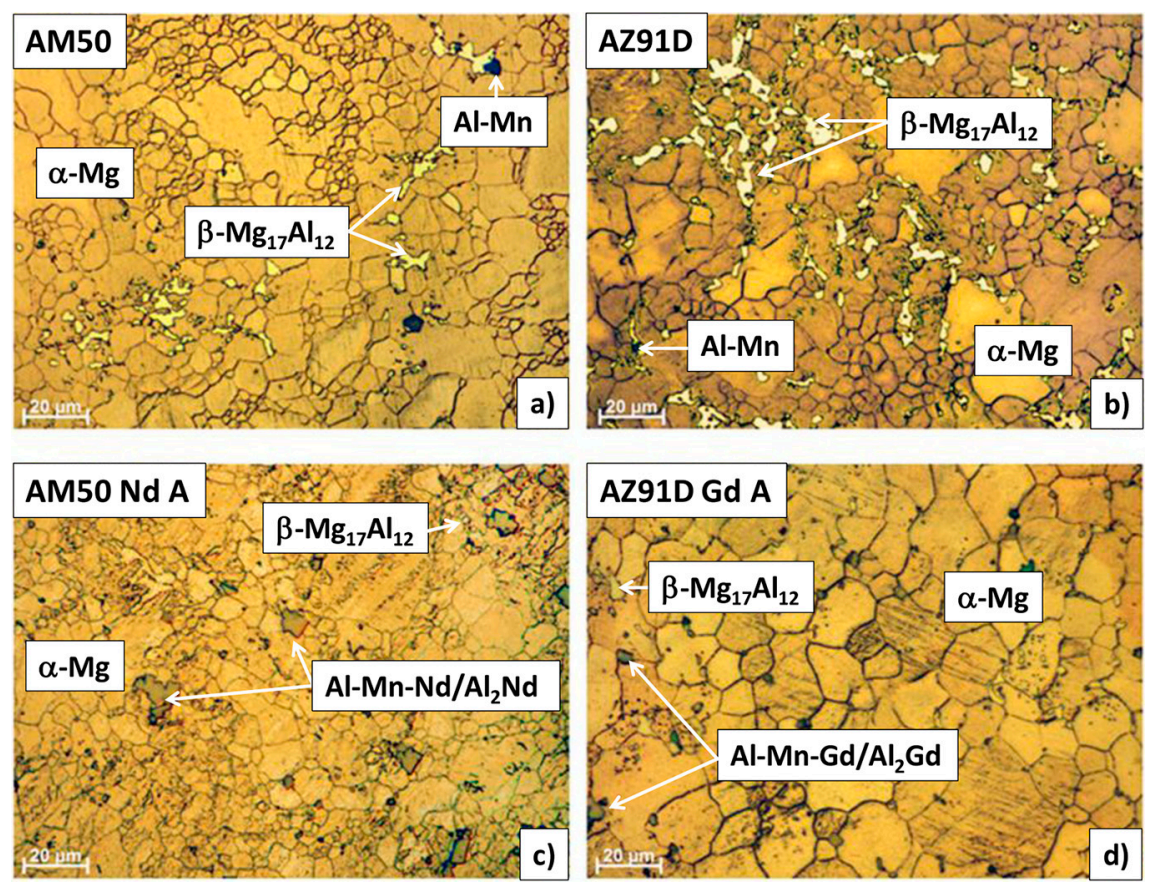

FIgure 1. Optical micrographs of : (a) AM50, (b) AZ91D, (c) AM50NdA and (d) AZ91DGdA alloys.

The AFM technique enabled the evaluation of the relative nobility of the different phases compared to the surrounding matrix (Fig. 3 and Fig. 4). According to the topographical images, surface potential images and potential profiles, the Al-Mn inclusions and $\mathrm{Al}-\mathrm{Mn}-\mathrm{Nd} / \mathrm{Al}_{2} \mathrm{Nd}$ appear exhibited a cathodic behaviour with potentials $\sim 300$ and $\sim 90 \mathrm{mV}$ higher, respectively, than that of the surrounding magnesium matrix. This suggested a stronger galvanic couple between the $\mathrm{Al}-\mathrm{Mn}$ inclusions and the $\alpha-\mathrm{Mg}$ phase. In case of $\mathrm{Al}-\mathrm{Mn}-\mathrm{Gd}$ and $\mathrm{Al}_{2} \mathrm{Gd}$ the potential values were slightly higher than those corresponding to Nd-containing intermetallics (Arrabal et al., 2012a and Arrabal et al., 2012b). These values were also comparable to those obtained by Liu, 2009c and Liu, 2010 for Al-RE intermetallics formed on the AM60 alloy modified with cerium or lanthanum.

\subsection{Electrochemical results}

\section{Potentiodynamic curves}

Polarization curves of studied alloys after 1 hour of immersion in 3.5 wt. $\% \mathrm{NaCl}$ solution are shown in Figure $5 \mathrm{a}$ and $5 \mathrm{~b}$. The corrosion potential values, $E_{\text {corr }}$, of unmodified and modified

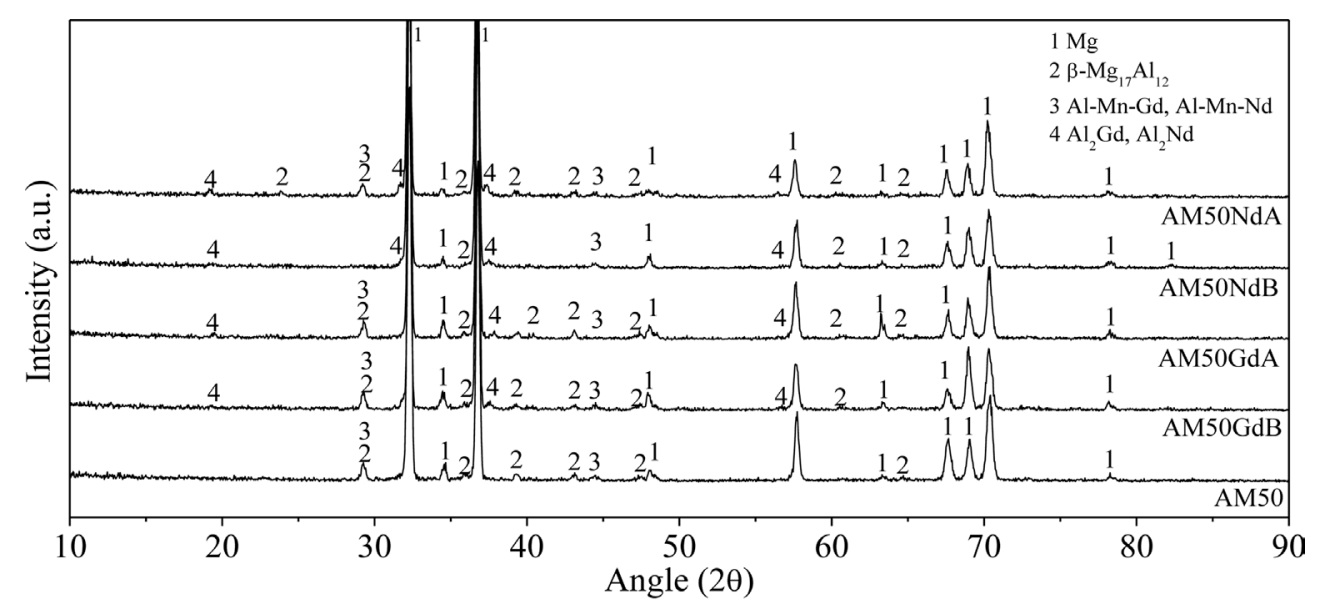

Figure 2. X-ray diffraction patterns of the studied alloys. 
a)

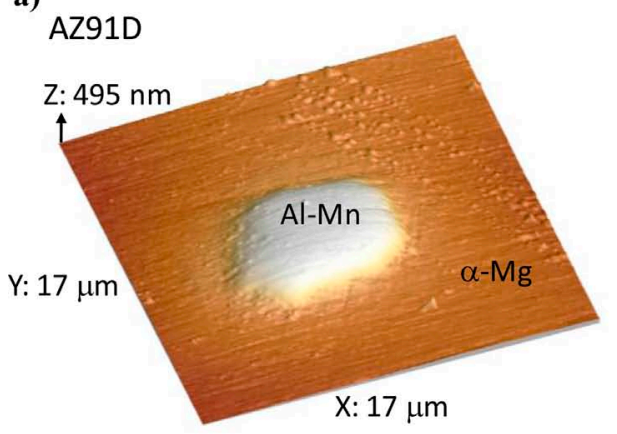

b)

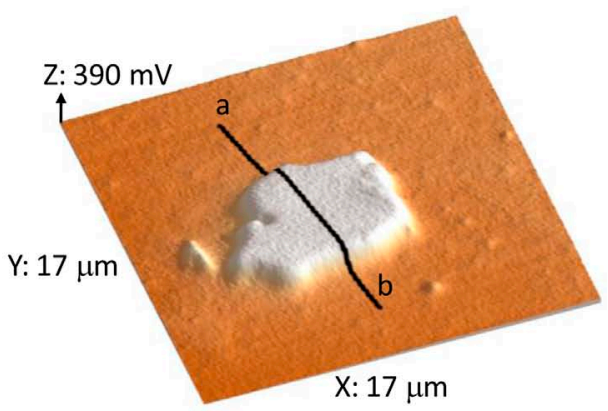

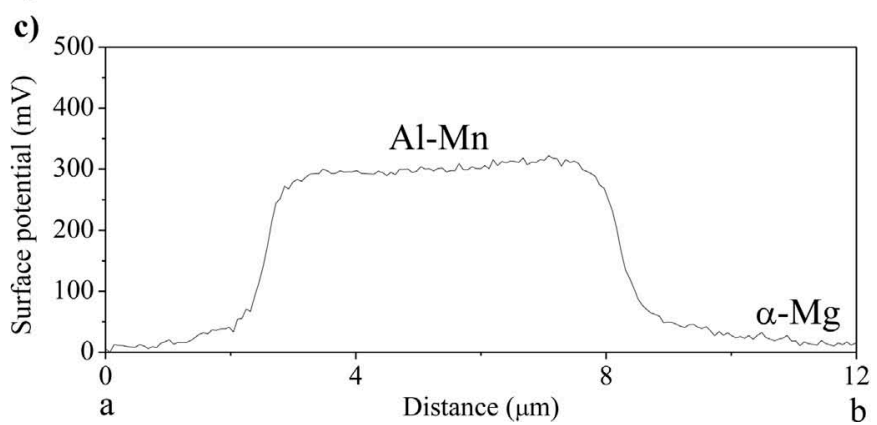

FIgURE 3. a) Topographic image; b) surface potential map and c) potential profile of an Al-Mn inclusion in the AZ91D alloy.

a)

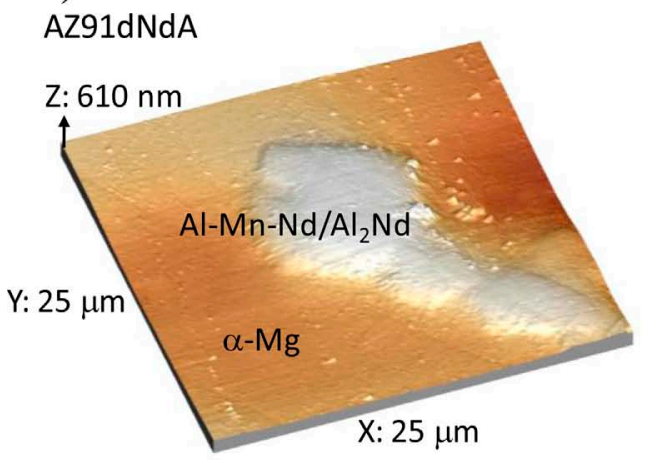

b)

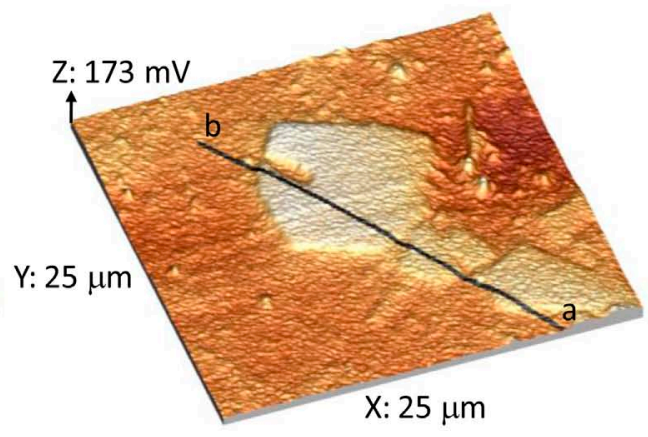

c)

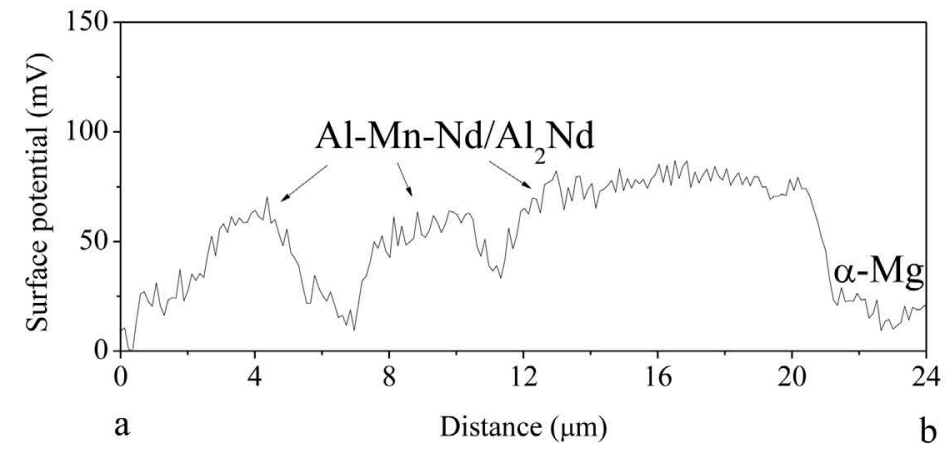

FIgURE 4. a) Topographic image; b) surface potential map and c) potential profile of an Al-Mn-Nd/Al 2 Nd inclusion in the AZ91DNdA alloy. 
AM50 and AZ91D alloys were around $-1.5 \mathrm{~V}_{\mathrm{Ag} /}$ $\mathrm{AgCl}$, indicating negligible influence of neodymium and gadolinium additions on this parameter. Carbon steel and the AA2011 alloy showed similar Ecorr values, close to $-0.96 \mathrm{~V}_{\mathrm{Ag} / \mathrm{AgCl}}$, whereas the AA6082 showed a more active potential at -1.1 $\mathrm{V}_{\mathrm{Ag} / \mathrm{AgCl}}$. The differences between the corrosion potential of the cathodic (AA2011, AA6082, steel) and the anodic member of the pair was about 0.5 $\mathrm{V}$ for both $\mathrm{Mg} / \mathrm{AA} 2011$ and $\mathrm{Mg} /$ steel couples and $0.42 \mathrm{~V}$ for the $\mathrm{Mg} / \mathrm{AA} 6082$ couples. This suggested similar galvanic corrosion behaviour of both steel and AA2011 materials and smaller galvanic corrosion rates for the galvanic couples with the AA6082 alloy.

Table 2 shows the electrochemical data (the electric potential, $E_{M}$, and the current density, $i_{M}$ ) obtained, according to the mixed potential theory, from the intersection of the two polarization curves of the individual constituent alloys. The unmodified AM50 alloy showed higher $i_{M}$ values than the AZ91D alloy: $\sim 3.5$ times higher for the galvanic couple with carbon steel, and $\sim 3$ times higher for those

a)

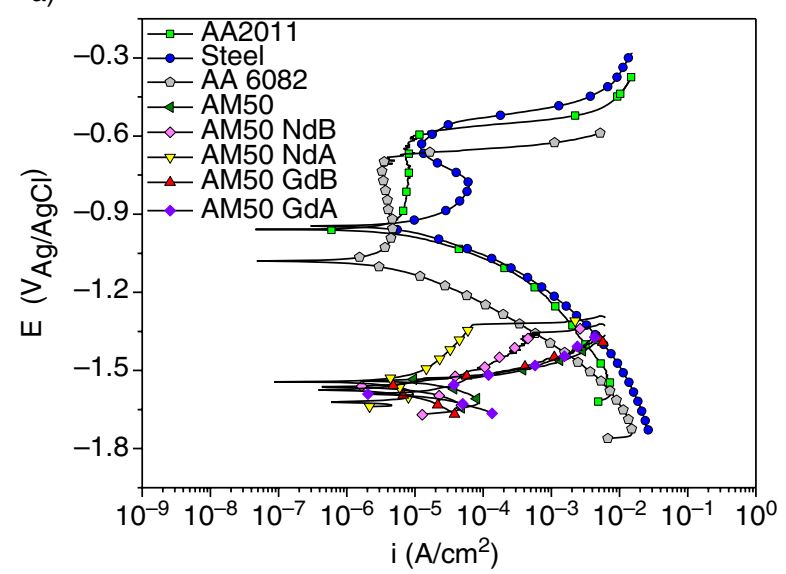

b)

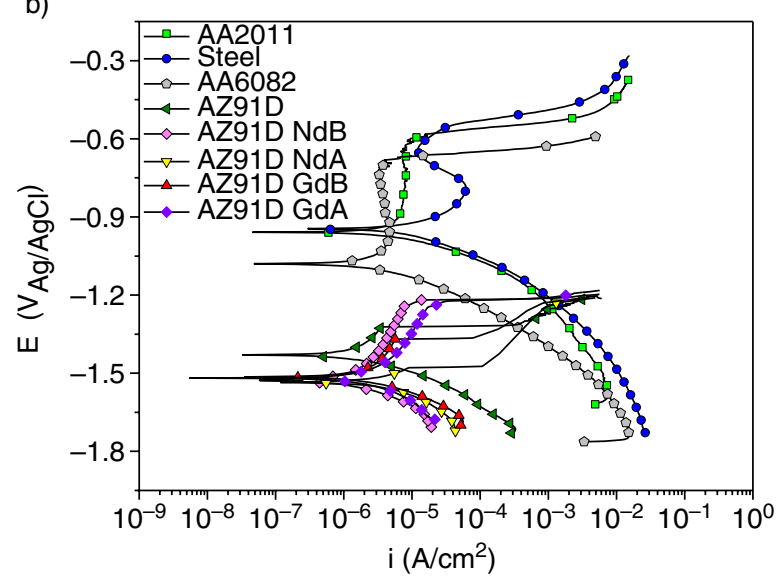

FIGURE 5. Polarization curves of studied alloys after 1hour of immersion in $3.5 \mathrm{wt} . \% \mathrm{NaCl}$ solution. with AA2011 and AA6082 alloys. The higher corrosion resistance of the AZ91D alloy is possibly due to the higher aluminium content in its a-phase and/or to the $\beta$-phase acting as physical barrier against corrosion attack (Splinter and McIntyre, 1994; Ambat et al., 2000; Liu et al., 2009d).

According to the mixed potential theory, the addition of RE slightly decreased the galvanic current density of both AM50 and AZ91D alloys. This effect was more remarkable for the AM50NdA and AZ91DNdB alloys with 0.8 wt. $\%$ and 0.7 wt. $\%$ Nd, respectively. According to the polarization curves in Figure 5, this improvement was related to the improved passive properties of the surface film, possibly due to incorporation of neodymium (Nordlien et al., 1997). The substitution of Al-Mn particles by less noble $\mathrm{Al}_{2} \mathrm{Nd}$ and $\mathrm{Al}-\mathrm{Mn}-\mathrm{Nd}$ particles may also have contributed to the improved galvanic corrosion behaviour of modified alloys, whereas a smaller area fraction of $\beta$-phase in the modified alloys does not seem to show a remarkable influence on the polarization curves. In case of gadolinium, the changes in the passivity of the surface film were less significant and the $\mathrm{Al}_{2} \mathrm{Gd}$ and $\mathrm{Al}-\mathrm{Mn}-\mathrm{Gd}$ intermetallics were slightly more noble than those containing neodymium. These factors could explain the higher galvanic corrosion current densities of Gd-modified alloys.

According to the values given in Table 2, the most compatible material was the AA6082 alloy, followed by the AA2011 alloy and the carbon steel. The latter two materials gave higher galvanic current densities due to the presence of metals having low hydrogen overvoltage, namely, $\mathrm{Cu}$-containing intermetallics in the AA2011 alloy (Osorio et al., 2012) and iron in the carbon steel.

\section{ZRA measurements}

Figure 6 shows the galvanic current density versus time of studied galvanic couples, where magnesium alloys always behave as anodes. For the AM50 alloys coupled to steel, the current increased from 5.9 to $7.1 \mathrm{~mA} \mathrm{~cm}^{-2}$ during the first 5 hours of immersion, possibly due to roughening of test panels caused by corrosion (Song et al., 2004), and then decreased linearly with increasing immersion time until values between 4.7 and $5.6 \mathrm{~mA} \mathrm{~cm}{ }^{-2}$ (Fig. 6a). The latter was possibly related to the formation of a layer of corrosion products on the AM50 alloys, which provided some protection and/or to the increasing $\mathrm{pH}$, which diminished the rate of the cathodic reaction on steel. Similarly to the $i_{M}$ values previously calculated by the mixed potential theory, the AM50 alloy showed the highest $i_{Z R A}$ values, whereas neodymium and gadolinium additions slightly reduced the intensity of the galvanic couple, in particular for the AM50NdA alloy which showed current values 1.2 times smaller than the AM50 alloy. In case of galvanic couples with aluminium alloys, the current 
TABLE 2. Electrochemical data (electric potential, $E_{M}$, and the current density, $i_{M}$ ) obtained according to the mixed potential theory

\begin{tabular}{|c|c|c|c|c|c|c|}
\hline \multirow[b]{2}{*}{ Alloy } & \multicolumn{2}{|c|}{ Steel } & \multicolumn{2}{|c|}{ AA2011 } & \multicolumn{2}{|c|}{ AA6082 } \\
\hline & $\begin{array}{c}E_{M} \\
\left(V_{\mathrm{Ag} / \mathrm{AgCl}}\right)\end{array}$ & $\begin{array}{c}i_{M} \\
\left(\mathrm{~mA} \mathrm{~cm}^{-2}\right)\end{array}$ & $\begin{array}{c}E_{M} \\
\left(V_{\mathrm{Ag} / \mathrm{AgCl}}\right)\end{array}$ & $\begin{array}{c}i_{M} \\
\left(\mathrm{~mA} \mathrm{~cm}^{-2}\right)\end{array}$ & $\begin{array}{c}E_{M} \\
\left(V_{\mathrm{Ag} / \mathrm{AgCl}}\right)\end{array}$ & $\begin{array}{c}i_{M} \\
\left(\mathrm{~mA} \mathrm{~cm}^{-2}\right)\end{array}$ \\
\hline AM50 & -1.382 & 5.228 & -1.415 & 3.582 & -1.468 & 1.381 \\
\hline $\mathrm{AM} 50 \mathrm{NdB}$ & -1.334 & 3.535 & -1.343 & 2.202 & -1.367 & 0.538 \\
\hline $\mathrm{AM} 50 \mathrm{NdA}$ & -1.306 & 2.714 & -1.312 & 1.809 & -1.323 & 0.355 \\
\hline AM50GdB & -1.374 & 4.914 & -1.402 & 3.274 & -1.425 & 1.235 \\
\hline AM50GdA & -1.366 & 4.656 & -1.399 & 3.147 & -1.434 & 1.266 \\
\hline AZ91D & -1.245 & 1.464 & -1.253 & 1.145 & -1.337 & 0.431 \\
\hline AZ91DNdB & -1.217 & 1.045 & -1.213 & 0.841 & -1.221 & 0.061 \\
\hline AZ91DNdA & -1.230 & 1.276 & -1.241 & 0.960 & -1.333 & 0.414 \\
\hline AZ91DGdB & -1.225 & 1.212 & -1.227 & 0.880 & -1.299 & 0.273 \\
\hline AZ91DGdA & -1.209 & 1.061 & -1.211 & 0.797 & -1.222 & 0.082 \\
\hline
\end{tabular}

gradually increased with immersion time for both AM50/AA2011 and AM50/AA6082 pairs. For longer immersion times, the rate of increase of $i_{Z R A}$ decreased, suggesting the formation of a slightly protective layer of corrosion products on the surface of AM50 alloys. In this case, the alkalization of the cathode surface is not expected to decrease the galvanic corrosion current since aluminium alloys readily dissolve in alkaline media. The AA6082 alloy was the most compatible material, whereas the presence of copper and iron in AA2011 and steel materials resulted in higher galvanic corrosion rates.

The dependence of $i_{Z R A}$ values with increasing time of AZ91D alloys coupled to steel was very similar to that observed in case of AM50/steel couples, i.e. the galvanic current gradually decreased with time due to formation of a protective layer of corrosion products on the surface and/or to alkalization effect of the steel surface. Comparison of the unmodified AZ91D alloy with the AM50 showed $i_{\text {ZRA }}$ values $\sim 1.2$ times smaller for the former after 1 day of immersion, confirming what the mixed potential theory predicted. Neodymium and gadolinium additions revealed a negative effect on the galvanic corrosion behaviour of the AZ91D alloy coupled to steel and there was no clear difference between the effect of gadolinium and that of neodymium. This behaviour was opposite to that predicted by the intersection of the polarization curves and could be related to the area fraction and morphology of the $\beta$-phase influencing the long-term corrosion behaviour of these alloys. It is known that a high area fraction of a finely divided and continuous $\beta$-phase in the AZ91D alloy tends to agglomerate on the surface due to selective corrosion of the $\alpha-\mathrm{Mg}$ phase, thus delaying the corrosion process (Shi et al., 2005). Therefore, a smaller area fraction of the $\beta$-phase in rare earth modified AZ91D alloys could prevent this from happening and explain the higher corrosion rates. Note that this barrier effect does not occur in the unmodified and modified AM50 alloys, hence a reduction of the $\beta$-phase in the AM50 alloys will always be beneficial.

The AZ91D alloy revealed smaller average $i_{Z R A}$ values than the AM50 alloy when coupled to the AA2011 alloy and higher values when coupled to the AA6082 alloy (Fig. 6e, 6f). Concerning the influence exerted by neodymium and gadolinium additions, two different trends were observed. Rare earth modified alloys coupled to AA2011 alloy revealed higher $i_{Z R A}$ values than the unmodified AZ91D alloy, but lower values when coupled to the AA6082 alloy. This apparently contradictory behaviour may again be explained by the area fraction and morphology of the $\beta$-phase. Thus, when the galvanic corrosion process is severe (AZ91D/steel and AZ91D/AA2011 couples), the barrier effect of the $\beta$-phase becomes important and modified AZ91D alloys, which possess a lower area fraction of $\beta$-phase, show higher galvanic corrosion rates. However, when the galvanic current is smaller (AZ91D/AA6082 couples), the previous effect is less significant and other factors come into play, which could also explained the higher $i_{\text {ZRA }}$ values of the AZ91D/AA6082 couples compared to the AM50/AA6082 ones. For instance, a higher area fraction of $\beta$-phase in the AZ91D alloy compared to the AM50 alloy would promote the breakdown of the surface film and enhance the anode reaction. Therefore, the effect of neodymium and gadolinium on the galvanic corrosion of the AZ91D is affected by many factors and no general trend can be obtained.

\subsection{Weight loss measurements}

Table 3 shows the galvanic corrosion rates calculated from gravimetric $\left(\mathrm{P}_{\mathrm{W}}\right)$ and electrochemical measurements $\left(\mathrm{P}_{\mathrm{M}}\right.$ : mixed potential theory, $\mathrm{P}_{\mathrm{ZRA}}$ : zero 
a)

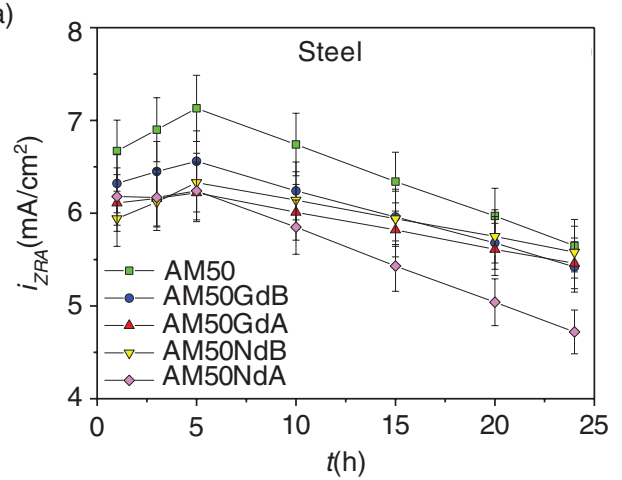

b)

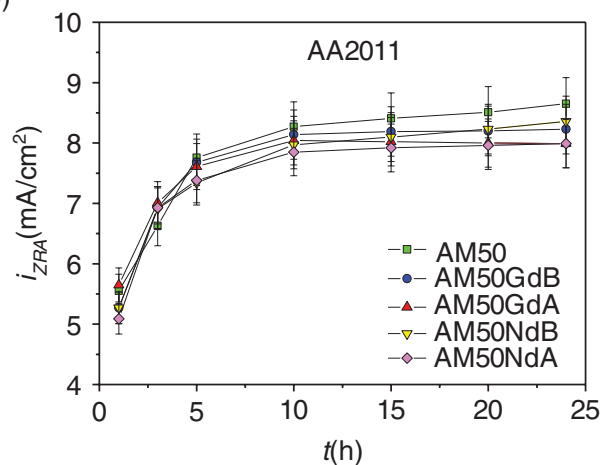

c)

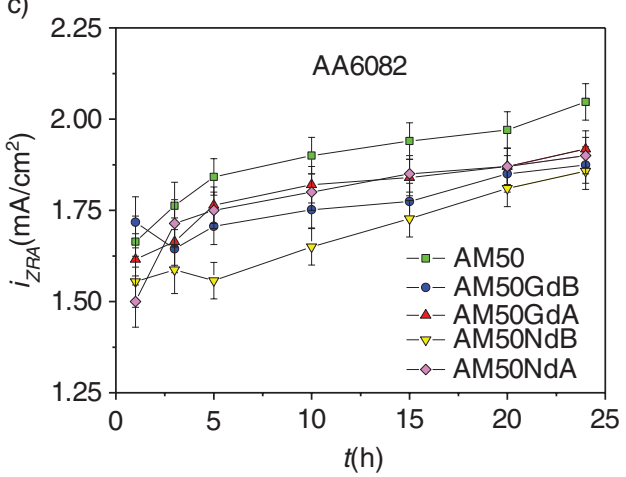

d)

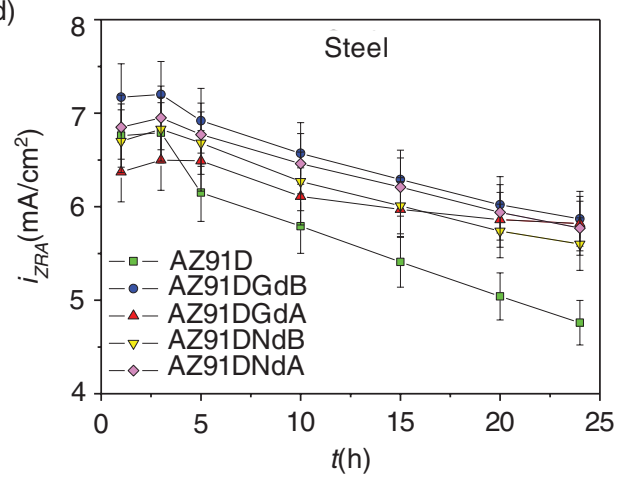

e)
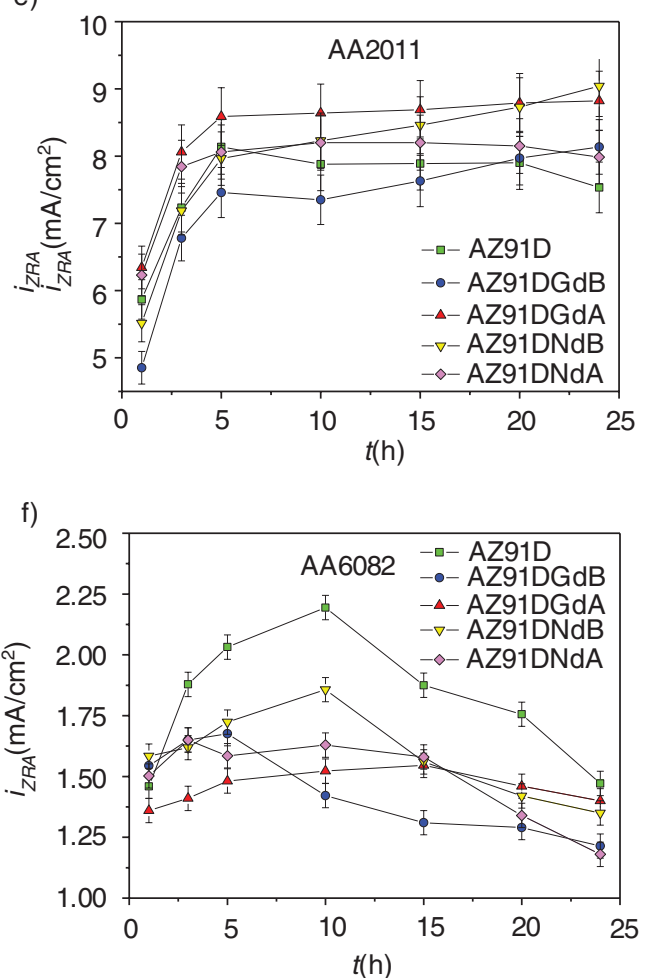

FIGURE 6. Galvanic current density versus time of studied galvanic couples.

resistance ammeter). All measurements gave corrosion rates that were 1 to 2 orders of magnitude higher than those of uncoupled alloys (Arrabal et al., 2012a; Arrabal et al., 2012b; Arrabal et al., 2012c), indicating the severity of the testing conditions. The corrosion rates calculated by the mixed potential theory were always lower than those obtained by the other methods. For instance, the corrosion rate of the AM50/ steel couple calculated by this method was between 15 and $40 \%$ lower than those obtained by ZRA and gravimetric measurements. These differences are in accordance with other studies (Desphande, 2010b) and may be associated with the fact that the mixed potential theory does not take into consideration the long-term corrosion behaviour of the real galvanic cell. When $P_{Z R A}$ and $P_{W}$ values are compared to each other, a similar ranking of the alloys was obtained; (i) the unmodified AZ91D alloy always revealed lower corrosion rates than the AM50, except when it was coupled to the AA6082 alloy; (ii) neodymium and gadolinium additions to the AM50 alloy resulted in similar or slightly smaller corrosion rates, especially in case of the AM50NdA alloy; (iii) neodymium and gadolinium additions to the AZ91D alloy were detrimental if this alloy was coupled to steel or to the AA2011 alloy, but beneficial if it was coupled to the AA6082 alloy; and (iv) the AA2011 alloy was the worst of the three cathode metals in terms of the measured galvanic corrosion rate. Despite this good correlation, the obtained values indicated that the ZRA measurements underestimated the amount of corrosion of unmodified and modified AM50 and 
TABLE 3. Results of the galvanic corrosion rates $\left(\mathrm{mg} \mathrm{cm}^{-2} \mathrm{~d}^{-1}\right)$ calculated from gravimetric (PW) and electrochemical measurements (PM: mixed potential theory, PZRA: zero resistance ammeter)

\begin{tabular}{|c|c|c|c|c|c|c|c|c|c|}
\hline \multirow[b]{3}{*}{ Alloy } & \multicolumn{9}{|c|}{ Corrosion rate $\left(\mathrm{mg} \mathrm{cm}^{-2} \mathrm{~d}^{-1}\right)$} \\
\hline & \multicolumn{3}{|c|}{ Steel } & \multicolumn{3}{|c|}{ AA2011 } & \multicolumn{3}{|c|}{ AA6082 } \\
\hline & $\mathrm{P}_{\mathrm{M}}$ & $\mathrm{P}_{\mathrm{ZRA}}$ & $\mathrm{P}_{\mathrm{W}}$ & $\mathrm{P}_{\mathrm{M}}$ & $\mathrm{P}_{\mathrm{ZRA}}$ & $\mathrm{P}_{\mathrm{W}}$ & $\mathrm{P}_{\mathrm{M}}$ & $\mathrm{P}_{\mathrm{ZRA}}$ & $\mathrm{P}_{\mathrm{W}}$ \\
\hline AM50 & 57 & 67 & 95 & 39 & 84 & 106 & 15 & 20 & 28 \\
\hline $\mathrm{AM} 50 \mathrm{NdB}$ & 38 & 62 & 96 & 24 & 81 & 102 & 6 & 19 & 27 \\
\hline $\mathrm{AM} 50 \mathrm{NdA}$ & 30 & 58 & 75 & 20 & 79 & 99 & 4 & 17 & 23 \\
\hline AM50GdB & 53 & 63 & 83 & 36 & 82 & 103 & 13 & 18 & 24 \\
\hline AM50GdA & 51 & 61 & 80 & 35 & 81 & 102 & 14 & 19 & 27 \\
\hline AZ91D & 16 & 59 & 71 & 12 & 78 & 102 & 5 & 41 & 56 \\
\hline AZ91DNdB & 11 & 64 & 76 & 9 & 85 & 108 & 0.7 & 31 & 42 \\
\hline AZ91DNdA & 14 & 66 & 87 & 10 & 84 & 105 & 5 & 35 & 47 \\
\hline AZ91DGdB & 13 & 67 & 76 & 10 & 81 & 108 & 3 & 38 & 48 \\
\hline AZ91DGdA & 12 & 64 & 79 & 9 & 89 & 118 & 0.9 & 32 & 47 \\
\hline
\end{tabular}

AZ91D alloys in comparison to weight loss measurements by 1.3 to 1.5 times. It is known that the zero resistance ammeter only measures the galvanic current and not the true corrosion rate (this is given by the sum of the galvanic corrosion rate and the selfcorrosion rate). Additionally, there is the "Negative Difference Effect" (NDE) effect, which also results in gravimetric measurements giving greater corrosion rates than electrochemical measurements (Shi et al., 2012). Nevertheless, both ZRA and gravimetric measurements gave comparable ranking of the alloys.

\subsection{Surface appearance and characterization of the corrosion products}

Figure 7 shows the surface morphology of representative galvanic couples after immersion in 3.5 wt. $\% \mathrm{NaCl}$ solution for 24 hours. Surface degradation of steel was negligible as it remained cathodically protected during the tests. However, there was noticeable degradation of both aluminium alloys due to local alkalization caused by consumption of $\mathrm{H}^{+}$in the cathodic reaction (Vargel, 2004). The AA2011 alloy showed a higher level of degradation than the AA6082 alloy. This is possibly associated with a more intense cathodic reaction due to the presence of $\mathrm{Cu}$-rich intermetallics and formation of a $\mathrm{Cu}$-rich smut on the surface, which are known to be very effective cathodes. The formation of a $\mathrm{Cu}$-rich smut, a common feature of 2xxx alloys in aqueous solutions (Campestrini et al., 2000), was confirmed by EDX analysis (61.5O-34.3Al-4.2 $\mathrm{Cu}$ at.\%).

Both unmodified and modified AM50 and AZ91D alloys coupled to steel and AA2011 showed severe galvanic corrosion regardless of gadolinium or neodymium additions due to the large potential difference and to the low hydrogen overvoltage of iron in the carbon steel and $\mathrm{Cu}$-rich surface in the AA2011 aluminium alloy. Although corrosion products were easily detached from the surface, the electrochemical measurements suggested that they still provided some corrosion protection. Figure 8 shows the backscattered scanning electron micrographs of the cross sections of representative galvanic couples after immersion in 3.5 wt. $\% \mathrm{NaCl}$ solution for 24 hours. Both AM50 and AZ91D alloy revealed localized corrosion that spread over the entire surface, resulting in general corrosion. The AZ91D alloy showed shallower corrosion compared to the AM50 related to a barrier effect of the $\beta-\mathrm{Mg}_{17} \mathrm{Al}_{12}$ phase.

When the AA6082 alloy was used as the cathode, galvanic corrosion was less intense and the alloys exhibited localized corrosion, which commenced around secondary phases $\left(\beta-\mathrm{Mg}_{17} \mathrm{Al}_{12}\right.$ and $\mathrm{Al}-\mathrm{Mn}$ inclusions) and at the centre of $\alpha-\mathrm{Mg}$ dendrites (Pardo et al., 2008; Song, 2005). Corroded areas were smaller but more numerous in the AZ91D alloys. This is believed to be associated with a greater area fraction of $\beta$-phase in the AZ91D alloys creating a more heterogeneous surface.

\section{CONCLUSIONS}

In this study, the effects of neodymium and gadolinium additions on the galvanic corrosion behaviour of AM50 and AZ91D magnesium alloys coupled to steel and two aluminium alloys were investigated. The following conclusions can be drawn:

1. Neodymium and gadolinium additions modified the microstructure of AM50 and AZ91D alloys, resulting in formation of $\mathrm{Nd}$-and Gd-containing intermetallics and a lower area fraction of $\beta-\mathrm{Mg}_{17} \mathrm{Al}_{12}$ phase. Under freely corroding conditions, rare earth modified alloys revealed higher corrosion resistance than the mother alloys due to increased surface passivity and suppression of micro-galvanic couples. 
Galvanic corrosion of rare earth modified AM50 and AZ91D magnesium alloys coupled to steel and aluminium alloys $\bullet 11$
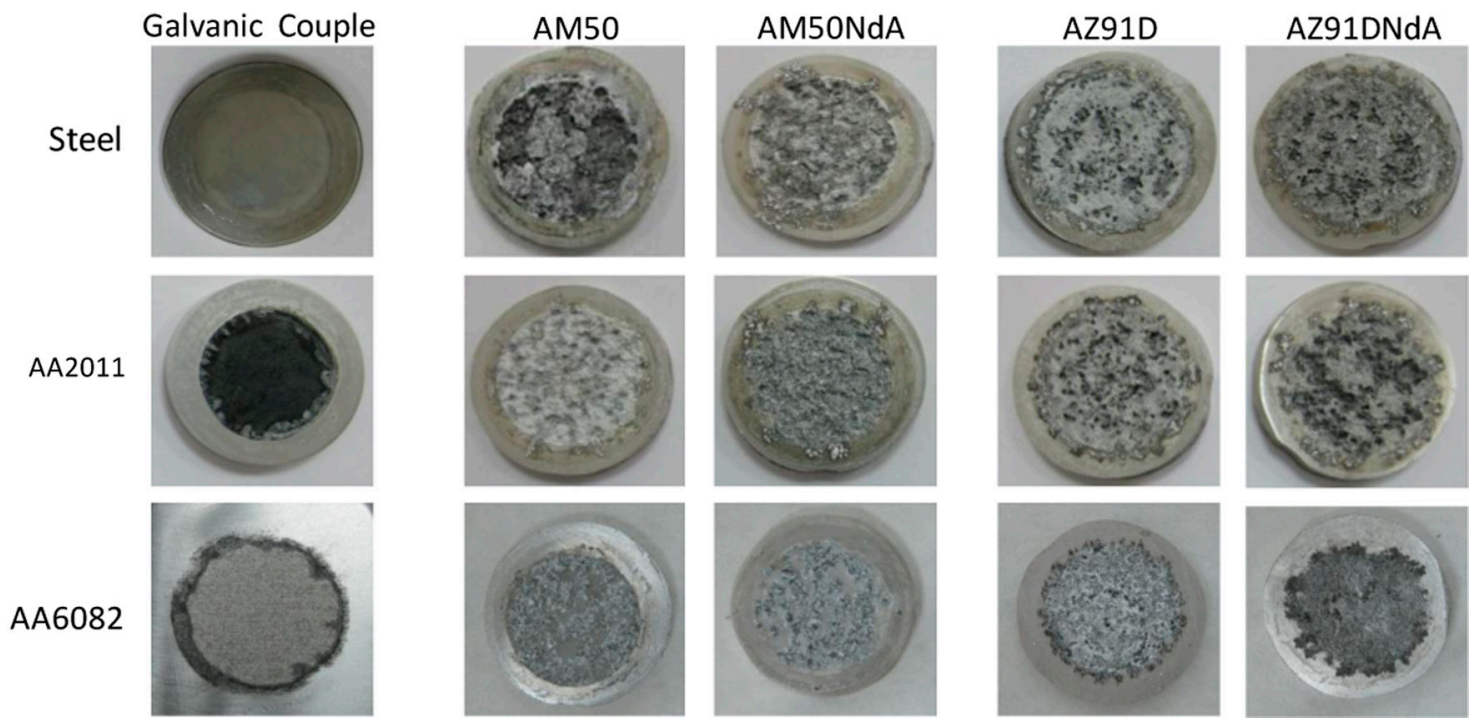

FIGURE 7. Surface appearance of representative galvanic couples after immersion in $3.5 \mathrm{wt} . \% \mathrm{NaCl}$ solution for 24 hours $\left(1.4 \mathrm{~cm}^{2}\right.$ working area).

2. The AA6082 alloy was the most compatible material and the AA2011 alloy was the least compatible due to the presence of $\mathrm{Cu}$-rich products on its surface. Steel revealed galvanic current values that were slightly smaller than those measured for the AA2011 alloy.

3. The effect of neodymium and gadolinium additions on the galvanic corrosion behaviour of the studied alloys depended on both the magnesium

a)

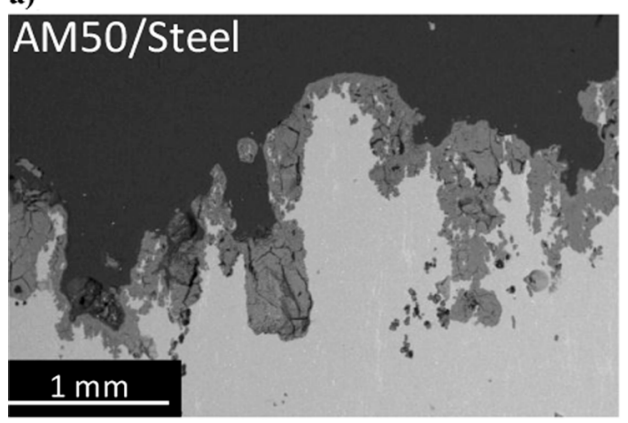

c)

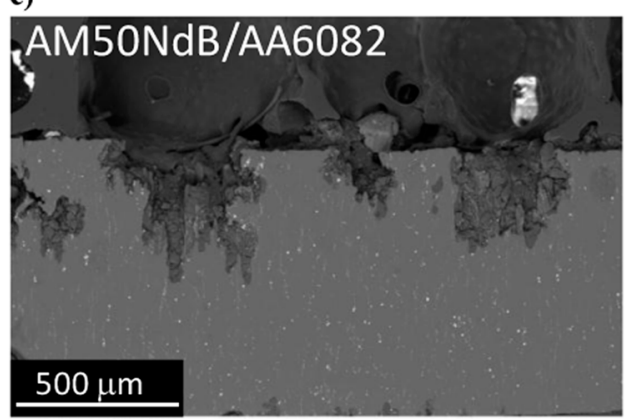

alloy and the cathode material. In case of the AM50 alloy, neodymium and gadolinium additions were always beneficial, with 0.8 wt. $\% \mathrm{Nd}$ giving the best results. However, the effect of neodymium and gadolinium on the galvanic corrosion behaviour of the AZ91D alloy was strongly influenced by the cathode material. Rare earth modified AZ91D alloys coupled to the AA2011 alloy and steel revealed higher

b)

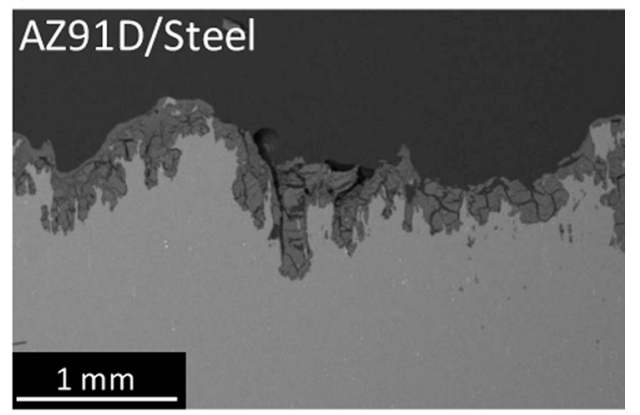

d)

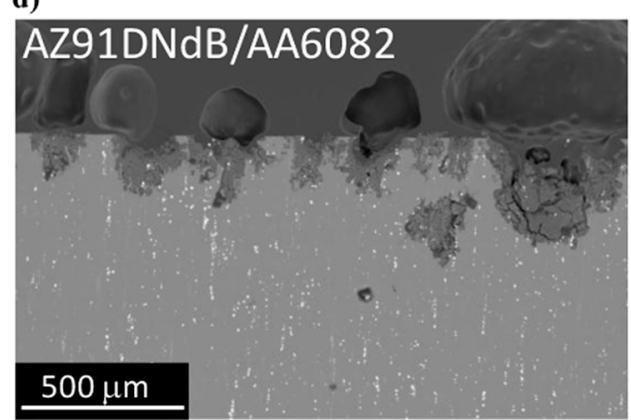

FIGURE 8. Backscattered electron micrograph of the cross-section of (a,b) AM50 and AZ91D coupled with steel and (c,d) AM50NdB and AZ91DNdB coupled with AA6082 after 24 hours of immersion in $3.5 \mathrm{wt} . \% \mathrm{NaCl}$ solution. 
corrosion rate values than the unmodified AZ91D alloy, but lower values when coupled to the AA6082 alloy. These results suggested that when the galvanic corrosion process is severe (AZ91D/steel and AZ91D/AA2011 couples), the barrier effect of the $\beta$-phase becomes important and modified AZ91D alloys, which possess a lower area fraction of $\beta$-phase, show higher galvanic corrosion rates. However, when the galvanic current is smaller (AZ91D/AA6082 couples), the previous effect is less significant and other factors become more important (passivity of the surface, nature of intermetallics, total interface area).

\section{ACKNOWLEDGEMENTS}

The authors are grateful to the MCYT (Spain, Project MAT 2009-09845-C02-01), the Community of Madrid (Spain, S2009MAT-1585) and the MANOEQ of Departamento de Metalurgia Física of CENIM (CSIC) for supply of the test materials. E. Matykina is grateful to the MICINN (Spain) for financial support via the Ramon y Cajal Programme (RYC-2010-06749). K. Paucar is grateful to the Fundación Carolina for funding a grant.

\section{REFERENCES}

Ambat, R., Aung, N.N., Zhou, W. 2000. Evaluation of Microstructural Effects on Corrosion Behaviour of AZ91D Magnesium Alloy. Corros. Sci. 42, 1433-1455. http:// dx.doi.org/10.1016/S0010-938X(99)00143-2.

Aoki, S., Kishimoto, K. 1991. Prediction of galvanic corrosion rates by the boundary element method. Math. Comput. Model. 15, 11-22. http://dx.doi.org//01016/0895-7177(91)90049-D.

Arrabal, R., Pardo, A., Merino, M.C., Mohedano, M., Casajus, P., Paucar, K., Garcés, G. 2012a. Effect of Nd on the corrosion behaviour of AM50 and AZ91D magnesium alloys in 3.5 wt. $\% \mathrm{NaCl}$ solution. Corros. Sci. 55, 301-312. http:// dx.doi.org/10.1016/j.corsci.2011.10.033.

Arrabal, R., Matykina, E., Pardo, A., Merino, M.C., Paucar, K. Mohedano, M., Casajus, P. 2012b. Corrosion behaviour of AZ91D and AM50 magnesium alloys with $\mathrm{Nd}$ and $\mathrm{Gd}$ additions in humid environments. Corros. Sci. 55, 351-362. http://dx.doi.org/10.1016/j.corsci.2011.10.038.

Arrabal, R., Pardo, A., Merino, M.C., Paucar, K., Mohedano, M. Casajus, P., Garcés, G. 2012c. Influence of Gd on the corrosion behaviour of AM50 and AZ91D magnesium alloys. Corrosion 68, 398-410. http://dx.doi.org/10.1016/j. corsci.2011.10.038

ASTM G82-98. 1998. Standard guide for development and use of a galvanic series for predicting galvanic corrosion performance, ASTM 3.02.

Bellucci, F. 1991. Galvanic corrosion between nonmetallic composites and metals. Corrosion 47, 808-819. http://dx.doi. org/10.5006/1.3585192

Campestrini, P., Westing, E.P.M., Rooijen, H.W., Wit, J.H.W 2000. Relation between microstructural aspects of AA2024 and its corrosion behaviour investigated using AFM scanning potential technique. Corros. Sci. 42, 1853-1861. http:// dx.doi.org/10.1016/S0010-938X(00)00002-0.

Desphande, K.B. 2010a. Validated numerical modelling of galvanic corrosion for couples: Magnesium alloy (AE44)mild steel and AE44-aluminium alloy (AA6063) in brine solution. Corros. Sci. 52, 3514-3522. http://dx.doi. org/10.1016/j.corsci.2010.06.031.
Desphande, K.B. 2010b. Experimental investigation of galvanic corrosion: Comparison between SVET and immersion techniques. Corros. Sci. 52, 2819-2826. http://dx.doi. org/10.1016/j.corsci. 2010.04.023.

Desphande, K.B. 2011. Numerical modeling of micro-galvanic corrosion. Electrochim. Acta. 56, 1737-1745. http://dx.doi. org/10.1016/j.electacta.2010.09.044.

Dong, C.F., Xiao, K., Li, X.G., Cheng, Y.F. 2010. Erosion accelerated corrosion of a carbon steel-stainless steel galvanic couple in a chloride solution. Wear 270, 39-45. http:// dx.doi.org/10.1016/j.wear.2010.09.004.

Friedrich, H., Schuman, S. 2001. Research for "a new age of magnesium" in the automotive industry. J. Mater. Process. Technol. 117, 276-281. http://dx.doi.org/10.1016/ S0924-0136(01)00780-4.

Guo, F., Li, P., Gao, X., Xu, J. 2010. Study on solid solution and aging process of AZ91D magnesium alloy with cerium. J. Rare Earth 28, 948-951. http://dx.doi.org/10.1016/ S1002-0721(09)60209-X.

Jia, J., Song, G.L., Atrens, A. 2006. Influence of geometry on galvanic corrosion on AZ91D coupled to steel. Corros. Sci. 48, 2133-2153. http://dx.doi.org/10.1016/j.corsci.2005.08.013.

Liu, C. Chen, D.L., Bhole, B., Cao, X, Jahazi, M. 2009a. Polishing-assisted galvanic corrosion in the dissimilar friction stir welded joint of AZ31 magnesium alloy to 2024 aluminum alloy. Mater. Charac. 60, 370-376. http://dx.doi. org/10.1007/s00170-013-5565-X.

Liu, N., Wang, J., Wang, V., Wu, Y., Wang, L. 2009b. Electrochemical corrosion behavior of $\mathrm{Mg}-5 \mathrm{Al}-0.4 \mathrm{Mn}-\mathrm{xNd}$ in $\mathrm{NaCl}$ solution. Corros. Sci. 51, 1328-1333. http://dx.doi. org/10.1016/j.corsci.2009.03.019.

Liu, W., Cao, F., Chang, Z., Zhang, J. 2009c. Effect of rare earth element $\mathrm{Ce}$ and $\mathrm{La}$ on corrosion behavior of AM60 magnesium alloy. Corros. Sci. 51, 1334-1343. http://dx.doi. org/10.1016/j.corsci.2009.03.018.

Liu, M., Uggowitzeru, J., Nagasekhar, A.V., Schmutz, P., Easton, M., Song, G.L., Atrens, A. 2009d. Calculated phase diagrams and the corrosion of die-cast $\mathrm{Mg}-\mathrm{Al}$ alloys. Corros. Sci., 51, 602-619. http://dx.doi.org/10.1016/j. corsci.2008.12.015

Liu, W., Cao, F., Chen, A., Chang, L., Zhang, J., Cao, C. 2010. Corrosion behaviour of AM60 magnesium alloys containing Ce or La under thin electrolyte layers. Part 1: Microstructural characterization and electrochemical behaviour. Corros. Sci. 52, 627-638. http://dx.doi.org/10.1016/j.corsci.2009.10.031.

Luo, A.A. 2004. Recent magnesium alloy development for elevated temperature applications. Int. Mater. Rev. 49, 13-30. http://dx.doi.org/10.1179/095066004225010497.

Makar, G.L., Kruger, J. 1990. Corrosion studies of rapidly solidified magnesium alloys. J. Electrochem. Soc. 137, 414-421. http://dx.doi.org/10.1149/1.2086455.

Makar, G.L., Kruger, J. 1993. Corrosion of magnesium. Int. Mater. Rev. 38,138-153.http://dx.doi.org/10.1179/imr.1993. 38.3.138.

Mc Cafferty, E. 1976. Calculation of current distribution in circular corrosion cells. Corros. Sci. 16, 186-190. http:// dx.doi.org/10.1016/0010-938X(76)90060-3.

Melville, P.H. 1980. Effect of the distribution of current within a pit on the variation in potential in the vicinity of the pit. J. Electrochem. Soc.127, 864-868. http://dx.doi.org/10. $1149 / 1.2129771$

Mercer, W.E., Hillis, J.E. 1992. SAE Technical Paper Series $\mathrm{N}^{\circ}$ 920073, Detroit, USA.

Nayyeri, M., Khomamizadeh, F. 2011. Effect of RE elements on the microstructural evolution of as cast and SIMA processed Mg-4Al alloy. J. Alloys Compd. 509, 1567-1572. http://dx.doi.org/10.1016/j.jallcom.2010.10.147.

Niu, J., Chen, Q., Xu, N., Wei, Z. 2008. Effect of combinative addition of strontium and rare earth elements on corrosion resistance of AZ91D magnesium alloy. Trans. Nonferrous Met. Soc. China 18, 1058-1064. http://dx.doi.org/10.1016/ S1003-6326(11)60780-2

Nordlien, J.H., Nisancioglu, K., Ono, S., Musuko, N. 1997. Morphology and structure of water-formed oxides on ternary MgAl alloys. J. Electrochem. Soc. 144, 461-466. http://dx.doi.org/10.1149/1.1837432. 
Osorio, W., Freire, C., Caram, R., Garcia, A. 2012. The role of Cu-based intermetallics on the pitting corrosion behavior of $\mathrm{Sn}-\mathrm{Cu}, \mathrm{Ti}-\mathrm{Cu}$ and $\mathrm{Al}-\mathrm{Cu}$ alloys. Electrochim. Acta 77, 189-197. http://dx.doi.org/10.1016/j. electacta.2012.05.106.

Pardo, A., Merino, M.C., Coy, A.E., Arrabal, R., Viejo, F. Matykina, E. 2008. Corrosion behaviour of magnesium/ aluminium alloys in $3.5 \mathrm{wt} . \% \mathrm{NaCl}$. Corros. Sci. 50, 823834. http://dx doi.org/10.1016/j.corsci.2007.11.005.

Rosalbino, F., Angelini, E., Negri, S., Saccone, A., Delfino, S. 2005. Effect of erbium addition on the corrosion behaviour of $\mathrm{Mg}-\mathrm{Al}$ alloys. Intermetallics 13, 55-60. http://dx.doi. org/10.1016/j.intermet.2004.05.007.

Senf, J., Broszeit, E., Gugau, M., Berger, C. 2000. TMS, Magnesium Technology 2000, Ed. H.I. Kaplan, Nashville, USA, pp. 137-142.

Shi, Z., Song, G.L., Atrens, A. 2005. Influence of the $\beta$ phase on the corrosion performance of anodised coatings on magnesiumaluminium alloys. Corros. Sci. 47, 2760-2777. http://dx.doi. org/10.1016/j.corsci.2004.11.004

Shi, Z., Liu, M., Atrens, A. 2010. Measurement of the corrosion rate of magnesium alloys using Tafel extrapolation. Corros. Sci. 52, 579-588. http://dx.doi.org/10.1016/j. corsci.2009.10.016.

Shi, Z., Jia, J., Atrens, A. 2012. Galvanostatic anodic polarisation curves and galvanic corrosion of high purity $\mathrm{Mg}$ in $3.5 \% \mathrm{NaCl}$ saturated with $\mathrm{Mg}(\mathrm{OH})_{2}$. Corros. Sci. 60, 296308. http://dx.doi.org/10.1016/j.corsci.2011.12.002.

Skar, J.I. 1999. Corrosion and corrosion prevention of magnesium alloys. Materials and Corrosion 50, 2-6. http://dx.doi. org/10.1002/(SICI) 1521-4176(199901)50:1<2::AID$\mathrm{MACO} 2>3.0 . \mathrm{CO} ; 2-\mathrm{N}$.

Skar, J.I. Albricht, D. 2002. TMS, Magnesium Technology 2002, Ed. H.I. Kaplan, Warrendale, USA, pp. 255-261.

Song, G.L., Atrens, A. 1999. Corrosion mechanisms of magnesium alloys. Adv. Eng. Mater. 1, 11-33. http://dx.doi. org/10.1002/(SICI) 1527-2648(199909)1:1<11::AIDADEM11>3.0.CO;2-N.

Song, G.L., Atrens, A. 2000. Corrosion and Environmental Degradation of Materials: Volume 19 of the Series: Materials Science and Technology, Ed. Wiley-VCH Verlag GmbH, USA.

Song, G.L., Johannesson, B., Hapugoda, S., StJohn, D. 2004. Galvanic corrosion of magnesium alloy AZ91D in contact with an aluminium alloy, steel and zinc. Corros. Sci. 46, 955977. http://dx.doi.org/10.1016/S0010-938X(03)00190-2.
Song, G.L. 2005. Recent progress in corrosion and protection of magnesium alloys. Adv. Eng. Mater. 7, 563-586. http:// dx.doi.org/10.1002/adem.200500013.

Song, Y.L., Liu, Y.H., Yu, S.R., Zhu, X.Y. 2007. Wang, S.H., Effect of neodymium on microstructure and corrosion resistance of AZ91 magnesium alloy. J. Mater. Sci. 42, 4435-4440. http://dx.doi.org/10.1007/s10853-006-0661-z.

Song, G.L. 2010. Potential and current distributions of onedimensional galvanic corrosion systems. Corros. Sci. 52, 455-480. http://dx.doi.org/10.1016/j.corsci.2009.10.003.

Splinter, S.J., McIntyre, N.S. 1994. The initial interaction of water vapour with $\mathrm{Mg}$ - $\mathrm{Al}$ alloy surfaces at room temperature. Surf. Sci. 314, 157-171. http://dx.doi.org/10.1016/ 0039-6028(94)90003-5.

Vargel, C. 2004. Corrosion of Aluminium, Ed. Elsevier, San Diego, USA, pp. 149-164

Yamasaki, M., Hayashi, n., Izumi, S., Kawamura, Y. 2007. Corrosion behavior of rapidly solidified $\mathrm{Mg}-\mathrm{Zn}$-rare earth element alloys in NaCl solution. Corros. Sci. 49, 255-262. http://dx.doi.org/10.1016/j.corsci.2006.05.017.

Yue, X., Sha, L. 2007. Corrosion resistance of AZ91D magnesium alloy modified by rare earths-laser surface treatment. J. Rare Earth. 25, 201-203. http://dx.doi.org/10.1016/ S1002-0721(07)60469-4

Zeng, R., Zhang, J., Huang, W., Dietzel, W., Kainer, K.U., Blawert, C., Ke, W. 2006. Review of studies on corrosion of magnesium alloys. Trans. Nonferrous Met. Soc. China 16, 763-771. http://dx.doi.org/10.1016/S1003-6326(06)60297-5.

Zhang, J.H., Wang, J., Qiu, X., Zhang, D.P., Tian, Z., Niu, X.D., Tang, D.X., Meng, J. 2008. Effect of Nd on the microstructure, mechanical properties and corrosion behavior of diecast Mg-4Al-based alloy. J. Alloys Compd. 464, 556-564. http://dx.doi.org/10.1016/j.jallcom.2007.10.056.

Zhang, J., Niu, X., Qiu, X., Liu, K., Nan, C., Tang, D., Meng, J. 2009. Effect of yttrium-rich misch metal on the microstructures, mechanical properties and corrosion behavior of die cast AZ91 alloy. J. Alloys Compd. 471, 322-330. http:// dx.doi.org/10.1016/j.jallcom.2008.03.089.

Zhang, T., Shao, Y., Meng, G., Cui, Z., Wang, F. 2011. Corrosion of hot extrusion AZ91 magnesium alloy: I-relation between the microstructure and corrosion behavior. Corros. Sci. 53, 1960-1968. http://dx.doi.org/10.1016/j.corsci.2011.02.015.

Zhao, M., Liu, M., Song, G.L., Atrens, A. 2008. Influence of the $\beta$-phase morphology on the corrosion of the $\mathrm{Mg}$ alloy AZ91. Corros. Sci. 50, 1939-1953. http://dx.doi. org/10.1016/j.corsci.2008.04.010. 